\title{
ANALISIS KEBERHASILAN SISTEM E-LEARNING SMK NEGERI 1 MALANG
}

\author{
Intan Sulistyaningrum Sakkinah \& Syaad Patmanthara \\ UniversitasNegeri Malang \\ e-mail:syaad@um.ac.id
}

\begin{abstract}
E-learning is one of the learning that is currently widely developed in educational institutions. SMK Negeri 1 Malang is one of the schools that have used e-learning but e-learning system SMK Negeri 1 Malang has not measured the success rate. Therefore the purpose of this study to determine the success of e-learning system SMK Negeri 1 Malang by using the analysis model DeLone and McLean. The results of this study indicate that e-learning SMK Negeri 1 Malang declared successful.
\end{abstract}

Keywords: DeLone and McLean, success model of information system, e-learning SMK Negeri 1 Malang.

\begin{abstract}
ABSTRAK
E-learning merupakan salah satu pembelajaran yang saat ini banyak dikembangkan di lembaga pendidikan. SMK Negeri 1 Malang merupakan salah satu sekolah yang telah menggunakan e-learning namun sistem e-learning SMK Negeri 1 Malang belum diukur tingkat keberhasilannya. Oleh sebab itu tujuan dari penelitian ini untuk mengetahui kerhasilan sistem e-learning SMK Negeri 1 Malang dengan menggunakan model analisis DeLone dan McLean. Hasil dari penelitian ini menunjukkan bahwa e-learning SMK Negeri 1 Malang dinyatakan berhasil.
\end{abstract}

Kata kunci: DeLonedan McLean, model keberhasilansisteminformasi, e-learning SMK Negeri 1 Malang

\section{PENDAHULUAN}

Seiring dengan perkembangan Teknologi Informasi (TI) yang semakin pesat, kebutuhan akan suatu konsep dan belajar mengajar berbasis TI menjadi tidak terelakkan lagi. Saat ini e-learning sudah banyak diterima oleh masyarakat dunia, terbukti dengan maraknya implementasi e-learning di lembaga pendidikan. Pemanfaatan TI merupakan salah satu indikator keberhasilan suatu insitusi pendidikan (Selim, 2007). Implementasielearning di SMK Negeri 1 Malangdiantaranya sebagai media penyedia materi mata pelajaran sesuai dengan kelas dan jurusan yang ada di SMK Negeri 1 Malang, selain itu e-learningdi SMK Negeri 1 Malangjuga dimanfaatkan sebagai media dalam melaksanakan tes secara online seperti ujian tengah semester maupun ujian semester.

E-learning SMK Negeri 1 Malang memiliki fitur berupa sajian mata pelajaran sesuai dengan program keahlian siswa dan kelas siswa, selain itu terdapat kolom ujian apabila terdapat jadwal ujian yang telah ditentukan oleh sekolah. Ketika siswa melakukan ujian dengan e-learning terdapat waktu yang berjalan sesuai dengan mata pelajaran yang diujikan. penelitian ini menggunakan model keberhasilan sistem informasi yang dikemukakan oleh DeLone dan McLean (2003) dengan enam variabel yaitu information quality, system quality, service quality, use, user satisfaction, dan net benefit.E-learningdi SMK Negeri 1 Malang terbilang baru dalam implementasinya sehingga diperlukan evaluasi terhadap sistem e-learning yang digunakan. Penelitian ini bertujuan untuk membuktikan bahwa model DeLone dan McLean dapat digunakan untuk menguji keberhasilan e-learningdi SMK Negeri 1 Malang dengan melihat hubungan antar variabel berdasarkan model DeLone dan McLean. 


\section{METODE}

Metode penelitian yang digunakan dalam penelitian ini adalah metode penelitian kuantitatif. Penelitian ini mengkorelasikan enam aspek kesuksesan sistem informasi yang dikemukakan oleh DeLone dan McLean (2003) yaitu: information quality, system quality, service quality, use, user satisfaction dan net benefit. Penelitian ini dilakukan pada bulan November 2016 di SMK Negeri 1 Malang.

Variabel dalam penelitian ini dibagi menjadi variabel eksogen dan endogen. Variabel eksogen terdiri atas kualitas sistem (system quality), kualitas informasi (information quality) dan kualitas layanan (service quality), sedangkan variabel endogen terdiri dari penggunaan sistem (use), kepuasan pengguna (user satisfaction), dan manfaat sistem (net benefit). Teknik pengambilan sampel yang dilakukan pada penelitian ini adalah teknik pengambilang sampel sistematis dengan subyek penelitian adalah seluruh siswa SMK Negeri 1 Malang. Sampel sistematik lebih menyebar dalam populasinya, dan hal ini terkadang menyebabkan penarikan sampel sistematik lebih teliti daripada penarikan sampel acak berlapis (Cochran, 2010:234). Sampel yang digunakan pada penelitian ini sejumlah 86 siswa.

Adapun langkah penelitian terdapat tiga tahap utama yaitu tahap persiapan, tahap pelaksanaan dan tahap akhir. Tahap persiapan terdiri dari observasi ke sekolah tempat penelitian yaitu SMK Negeri 1 Malang, mengetahui jumlah populasi pada penelitian dan sampel penelitian, mempersiapkan instrumen yang akan digunakan, melakukan uji coba instrumen dan revisi instrumen apabila diperlukan. Tahap pelaksanaan terdiri dari memberikan angket kepada responden. Tahap akhir terdiri dari mengumpulkan data jawaban responden dan menganalisis data.

Proses pengambilan data dilakukan dengan memberikan lembar kuesioner kepada responden. Data yang diperoleh adalah data kuantitatif. Analisis data dilakukan dengan analisis korelasi product moment pearson. Sebelum melakukan uji hipotesis terlebih dahulu dilakukan uji normalitas yang berfungsi untuk mengetahui distribusi data.

\section{HASIL}

Tabel 1. Hasil Analisis Data

\begin{tabular}{llllll}
\hline & KS & KI & U & KP & NB \\
& & & & & \\
\hline KS & & $\mathrm{Ha}_{(3)}$ & $\mathrm{Ha}_{(1)}$ & $\mathrm{Ha}_{(2)}$ & \\
& & 0,681 & 0,518 & 0,584 & \\
KI & $\mathrm{Ha}_{(3)}$ & & & $\mathrm{Ha}_{(3)}$ & \\
& 0,681 & & & 0,698 & \\
KL & & & $\mathrm{Ha}_{(4)}$ & & \\
& & & 0,227 & & \\
U & & & & $\mathrm{Ha}_{(5)}$ & $\mathrm{Ha}_{(6)}$ \\
& & & & 0,435 & 0,239 \\
KP & & & & & $\mathrm{Ha}_{(7)}$ \\
& & & & & 0,521 \\
NB & & & $\mathrm{Ha}_{(8)}$ & $\mathrm{Ha}_{(8)}$ & \\
& & & 0,239 & 0,521 & \\
\hline
\end{tabular}

Tabel 1 menunjukkan hasil analisis data hubungan variabel kualitas sistem (system quality) yang diwakili KS, kualitas informasi (information quality), kualitas layanan (service quality) yang diwakili KL, penggunaan (use) yang diwakili $\mathrm{U}$, kepuasan pengguna (user satisfaction) yang diwakili KP dan manfaatmanfaat bersih (net benefit) yang diwakili NB.

Kualitas sistem memiliki hubungan positif dengan penggunaan dengan nilai $r$ hitung $=0,518$. Hal ini dapat diartikan bahwa ketika sistem memiliki kualitas yang baik dapat meningkatkan penggunaan sistem oleh pengguna e-learning SMK Negeri 1 Malang. Hasil pengujian tersebut juga sesuai dengan penelitian yang dilakukan oleh Livari (2005) dan Fan dan Fang (2006) yang juga menyatakan bahwa variable kualitas system (system quality) memiliki pengaruh yang signifikan terhadap variable penggunaan system (use).

Kualitas sistem memiliki hubungan positif terhadap kepuasan pengguna dengan nilai $r$ hitung $=0,584$. Dengan kata lain apabila 
kualitas sistem yang dihasilkan baik, maka dapat mempengaruhi tingkat kepuasan pengguna terhadap sistem e-learning SMK Negeri 1 Malang. Hasil penelitian ini sesuai dengan penelitian yang dilakukan oleh Wang dan Hu (2009) dan Fan dan Fang (2006) yang juga menyatakan bahwa kualitas sistem memiliki pengaruh positif terhadap variabel kepuasan pengguna.

Kualitas informasi dan kualitas sistem memiliki hubungan positif dengan variabel penggunaan dengan nilai $r$ hitung $=0,503$, hal ini menunjukkan bahwa apabila kualitas sistem dan kualitas informasi yang disajikan oleh sistem baik maka dapat meningkatkan penggunaan e-learning SMK Negeri 1 Malang. Hal ini sesuai dengan hasil penelitian yang dilakukan oleh Fan dan Fang (2006) yang juga menyatakan bahwa variabel kualitas informasi dan kualitas sistem memiliki pengaruh/hubungan dengan variabel penggunaan.

Kualitas informasi memiliki hubugnan positif terhadap kepuasan pengguna dengan nilai $\mathrm{r}$ hitung $=0,698$. Hal ini menjelaskan bahwa kualitas informasi yang diberikan sistem dapat mempengaruhi tingkat kepuasan pengguna. Hal ini sesuai dengan penelitian yang dilakukanoleh Salim (2014), Wang (2009), Livari (2005) serta Montesdioca dan Macada (2015) yang juga menyatakan bahwa kualitas informasi (information quality) memiliki hubungan positif terhadap kepuasan pengguna (user satisfaction).

Kualitas layanan memiliki hubungan terhadap tingkat penggunaan sistem e-learning SMK Negeri 1 Malang dengan nilai $r$ hitung = 0,227 . Hal ini sesuai dengan penelitian yang dilakukan Salim (2014) dan Wang dan $\mathrm{Hu}$ (2009) yang juga mengatakan bahwa terdapat hubungan positif dan signifikan antara variabel kualitas layanan dengan penggunaan sistem.

Variabel penggunaan memiliki hubungan positif dengan variabel kepuasan pengguna dengan nilai $r$ hitung $=0,435$, hal ini menjelaskan bahwa tingkat penggunaan sistem e-learning SMK Negeri 1 Malang (use)dapat menunjukkan tingkat kepuasan pengguna.
Hasil penelitian ini didukung oleh penelitian yang dilakukan oleh Livari (2005) yang juga menyatakan bahwa terdapat hubungan antara variabel penggunaan terhadap kepuasan pengguna.

Terdapat hubungan positif antara penggunaan dan manfaat yang didapatkan dengan nilai $r$ hitung $=0,239$, hal ini menunjukkan bahwa tingkat penggunaan sistem e-learningSMK Negeri 1 Malang (use) dapat menjadi indikasi terhadap manfaat yang didapatkan oleh pengguna. Hal ini sesuai dengan hasil penelitian yang dilakukan oleh Salim (2014) dan Livari (2005) yang juga mengatakan bahwa variabel sistem memiliki hubungan positif terhadap variabel manfaat yang didapatkan.

Terdapat hubungan positif antara kepuasan pengguna dengan manfaat yang didapatkan dengan nilai $\mathrm{r}$ hitung $=0,521$, hal ini menunjukkan bahwa tingkat kepuasan pengguna sistem e-learning SMK Negeri 1 Malang (user satisfaction) dapat menjadi salah satu indikasi bahwa pengguna mendapatkan manfaat dari sistem e-learning SMK Negeri 1 Malang. Hal ini sesuai dengan penelitian yang dilakukan oleh Kusumawati (2013) danHadi (2015) yang juga mengatakan bahwa variabel kepuasan pengguna memiliki hubungan yang positif dengan variabel manfaat yang didapatkan.

Variabel manfaat yang didapatkan (net benefit) memiliki hubungan positif dengan kepuasan pengguna dan penggunaan dengan nilai $r$ hitung $=0,478$, sehingga dapat diketahui bahwamanfaat yang didapatkan oleh pengguna dapat mempengaruhi tingkat penggunaan dan tingkat kepuasan pengguna sistem e-learning SMK Negeri 1 Malang.Hal ini didukung penelitian yang dilakukan oleh Salim (2014) serta Wang dan Hu (2009) yang juga menyatakan bahwa manfaat yang didapat memiliki pengaruh/hubungan terhadap penggunaan sistem dan kepuasan pengguna.

Berdasarkan teori yang dikemukakan oleh DeLone dan McLean (2003) dijelaskan bahwa suatu sistem informasi dapat diakatakan sukses/berhasil apabila terdapat hubungan 
yang positif antar variabel-variabel yang diteliti. Dari penjelasan tersebut maka penerapan sistem e-learning SMK Negeri 1 Malang dapat dikatakan sukses/berhasil.

\section{SIMPULAN}

Berdasarkan hasil dari penelitian yang telah dilakukan maka dapat disimpulkan sebagai berikut.Terdapat hubungan positif antara variabel kualitas sistem dan variabel penggunaane-learning SMK Negeri 1 Malang, terdapat hubungan positif antara variabel kualitas sistem dengan variabel kepuasan penggunae-learning SMK Negeri 1 Malang, terdapat hubungan positif antara variabel kualitas informasi dan kualitas sistem terhadap variabel penggunaan sisteme-learning SMK Negeri 1 Malang, terdapat hubungan positif antara variabel kualitas informasi dengan variabel kepuasan pengguna e-learning SMK Negeri 1 Malang, terdapat hubungan positif antara variabel kualitas layanan dengan penggunaan sistem e-learning SMK Negeri 1 Malang, terdapat hubungan positif antara variabel penggunaan sistem dengan kepuasan pengguna e-learning SMK Negeri 1 Malang, terdapat hubungan positif antara variabel penggunaan sistem dan manfaat yang didapatkan e-learning SMK Negeri 1 Malang, terdapat hubungan positif antara variabel kepuasan pengguna dan manfaat yang didapatkan e-learning SMK Negeri 1 Malang, terdapat hubungan positif antara variabel manfaat yang didapatkan terhadap penggunaan sistem dan kepuasan pengguna e-learning SMK Negeri 1 Malang dan terdapat hubungan positif antar variabel-variabel yang diteliti. Hasil penelitian ini menunjukkan bahwa $e$ learning SMK Negeri 1 Malang dapat dikatakan sukses.

Berdasarkan kajian yang telah dipaparkan, maka saran yang diajukan dirumuskan sebagai berikut: (1) untuk penelitian selanjutnya bisa menambah jumlah indikator sehingga bisa dilakukan pengujian secara mendalam; (2) bagi sekolah hendaknya dapat meningkatkan kualitas informasi dan kualitas sistem serta dapat lebih memotivasi siswa untuk menggunakan e-learning SMK Negeri 1 Malang; dan (3) bagi siswa hendaknya dapat menggunakan e-learning SMK Negeri 1 Malang yang telah disediakan dalam kegiatan belajar sehari-hari sehingga $e$ learning SMK Negeri 1 Malang dapat berfungsi secara optimal.

\section{DAFTAR RUJUKAN}

Cochran, William G. 2010. Teknik Penarikan Sampel. Jakarta: Penerbit Universitas Indonesia (UI-Press).

DeLone, W. H., McLean, E. R. 2003. The DeLone and McLean Model of Information Systems Success: A TenYear Update. Journal Management Information System, 19(4): 9-30.

Fan, Jeff C., Fang, Kwoting. 2006. ERP Implementation and Information System Success: A Test of DeLone and McLean's Model. PICMET: 1272-1278.

Hadi, Husnul. 2012. Efektifitas Sistem Informasi Perpustakaan Sekolah di SMAN 1 Godean. Skripsi.Yogyakarta: UniversitasNegeri Yogyakarta.

Kusumawati, Aris. 2013. Analisis Kualitas Sistem Informasi Terhadap Peningkatan Produktivitas dan Pengetahuan Mahasiswa Sebagai Pengguna Media Pembelajran Berbasis E-Learning. Jurnal Teknik POMITS. (Online), (http://digilib.its.ac.id), diakses 20 November 2016.

Livari, Juhani. 2005. An Empirical Test of the DeLone-McLean Model of Information System Success. Database for Advance in Information System (DFA), 36: 8-27.

Montesdioca, Gustavo Percio Z., Macada, Antonio Carlos Gastaud 2015. Quality Dimensions of the DeLone-McLean Model to Measure User Satisfaction: an Empirical Test on the Information Security Context. IEEE Computer Society, 15: 5010-5019. 
Salim, Muhammad Islam. 2014. Analisis Kesuksesan Sistem Informasi Perpustakaan Senayan dengan Pendekatan Model DeLone dan McLean di SMK Muhammadiyah 3 Yogyakarta. Skripsi.Yogyakarta: UniversitasNegeri Yogyakarta.
Wang, Haiping., Hu, Zhengming. 2009. Applying DeLone and McLean Information System Model to Online Consumer Behavior in China. International Conf. On Management of E-Commerce and e-Government:74-77. 